\title{
The Admissibility of Unlawfully Obtained Evidence before International Courts and Tribunals
}

\author{
Sara Mansour Fallah \\ Faculty of Law, University of Vienna, Vienna, Austria \\ sara.mansour.fallah@univie.ac.at
}

\begin{abstract}
70 years ago, the International Court of Justice decided its first and potentially most important case involving unlawfully obtained evidence. Despite clearly rejecting 'discovery by intervention', the judgment left many guessing as to the consequences for evidence obtained through such violations. As parties to international disputes have certainly not become less inclined to obtain evidence by unlawful means, the question arises: Was this old confusion ever unraveled? This article discusses whether today, there are international rules or principles governing the admissibility of unlawfully acquired evidence and applies a two-fold approach. First, it examines traditional sources of international law, including international jurisprudence, and second, it scrutinizes the frequently drawn analogy to national jurisdictions by surveying their treatment of illegally obtained evidence. Although a generally binding "inadmissibility rule" does not yet exist, practice demonstrates a tendency to consider such evidence in light of general principles of law. This article proposes handling unlawfully acquired evidence by applying a defined, yet flexible balancing test using criteria commonly applied in international and national practice.
\end{abstract}

\section{Keywords}

evidence in international law - illegally obtained evidence - admissibility of evidence discovery in international adjudication - leaks 


\section{Introduction}

Preserving the integrity of judicial proceedings and achieving a factually correct outcome are sometimes directly opposed objectives. The dilemma is manifest when a party to a dispute puts forth a document obtained in violation of the opponent's territory, diplomatic premises, or cyberspace. International courts, however, seem strikingly lenient towards evidence obtained by breaching the very law the proceedings seek to enforce. With only a few exceptions in international criminal law, statutes and rules of international courts and tribunals predominantly remain silent on the admissibility of unlawfully acquired evidence. Although some consider this silence a necessary grant of evidentiary flexibility to judicial bodies, this article argues that it is rather a situation of risky non-regulation.

The approach of general admissibility to such evidence neither seemed to bear scrutiny in the past, nor does it stand the modern-day pace of cyberattacks, leaks, and other intrusions into sovereign spheres. Although already in 1949, through its judgment in Corfu Channel (United Kingdom of Great Britain and Northern Ireland v. Albania), the International Court of Justice (ICJ) triggered debates on the existence of an 'exclusionary rule' in international law, not much has happened in terms of clarifying applicable rules and principles ever since. While the judgment's language clearly indicated the undesirability of unlawful discovery of evidence in international litigation, it failed to act on this stance. In light of the topic of "evidence before international courts and tribunals" having recently been added to the International Law Commission's (ILC) long-term working program, ${ }^{1}$ including the question "whether there are rules of admissibility of evidence and, if so, which rules of admissibility could be applied,"2 it appears timely to revisit the issue of illegally obtained evidence.

This article aims to examine whether, after the Court's treatment of unlawfully acquired evidence in Corfu Channel, a rule or principle of international law has crystallized, obliging courts or tribunals to reject evidence acquired in violation of international law. For this purpose, the article will first examine procedural frameworks of international courts and tribunals and treaty provisions that regulate the admission of unlawfully acquired evidence (see infra, 2), as well as how and under which guiding principles international courts and tribunals have dealt with such evidence (see infra, 3 ). In an effort to obtain

1 International Law Commission, Report on the Work of Its Sixty-Ninth Session, 2017, GAOR Records, Supplement No. 10 (A/72/10), pp. 213 and 246.

2 Ibid., Annex B, p. 246. 
further guidance on the issue, the article will look at general principles of law by discerning guidelines derived from national laws and practices (see infra, 4). The lessons learned from national laws and international jurisprudence shall then be revisited with the aim of identifying a way of handling such evidence in the international sphere to achieve greater procedural justice and transparency in the development of the law in this field (see infra, 5). While this article focuses on rules of the ICJ and other state-to-state proceedings, it will, where necessary, include findings of international criminal courts or tribunals and investment tribunals.

\section{Procedural Rules and Treaty Provisions}

Until recently, little attention has been paid to the drafting of procedural rules applicable in international courts and tribunals; the focus has rather rested on the more controversial issue of substantive law. ${ }^{3}$ The main procedures were set out in constitutive documents, mostly statutes, and all other 'technical, hence uncontroversial' matters were left to the self-regulation of the newly created judicial institutions. ${ }^{4}$ In the many statutes and rules of procedure of international courts and tribunals, provisions on evidence are hence not pronounced in great detail. ${ }^{5}$ If they are, they address 'formalities' (e.g. the production or taking of evidence), rather than standards regulating admissibility or appreciation of evidence. ${ }^{6}$ Admissibility of evidence is usually an issue that is not only left to self-regulation, but to 'non-regulation' in the sense that courts and tribunals themselves have only rarely exercised their regulatory power to set out rules on admissibility. ${ }^{7}$ It follows from the absence of rules in constitutive

3 Durward V. Sandifer, Evidence before International Tribunals (1971), 29.

4 E.g. Statute of the International Court of Justice, Article 3o(1); Elihu Lauterpacht, "Principles of Procedure in International Litigation", 345 Recueil des Cours de l'Académie de Droit International 387 (2011), 501-502; Daniel Joyce, "Fact-Finding and Evidence at the International Court of Justice: Systemic Crisis, Change or More of the Same", 18 Finnish Yearbook of International Law (2007), 283, 286.

5 Supra note 1, at 243; Chester Brown, A Common Law of International Adjudication (2007), 86.

6 Anna Riddell and Brendan Plant, Evidence before the International Court of Justice (2016), 2; Rüdiger Wolfrum, "International Courts and Tribunals, Evidence", in R. Wolfrum (ed.), Max Planck Encyclopedia of Public International Law (2012), 553.

7 Riddell and Plant, supra note 6, at 152; Charles N. Brower, "Evidence Before International Tribunals: The Need for Some Standard Rules", 28 International Lawyer (1994), 47, 48 (in relation to arbitral tribunals). 
documents that international adjudicative bodies and their judges enjoy wide discretion with respect to the admission and appreciation of evidence. ${ }^{8}$

The procedural framework of the ICJ (consisting of the Statute, Rules of Court, and Practice Directions) only regulates a limited range of evidentiary matters. ${ }^{9}$ These include provisions for the production ${ }^{10}$ and taking of evidence, ${ }^{11}$ appointment of experts, ${ }^{12}$ examination of witnesses, ${ }^{13}$ and on-site visits. ${ }^{14}$ Central issues such as the admissibility and evaluation of evidence, however, are not prominently covered. The only provisions that may be considered to speak to the admissibility of evidence are those restricting the late submission of evidence, ${ }^{15}$ or those prescribing that annexes should only contain relevant documents. ${ }^{16}$ Article 30, paragraph 1, of the ICJ Statute puts forth that the Court "shall frame rules for carrying out its functions" and "lay down rules of procedure."17 The ICJ has not fully exercised this rule-making power with respect to the admissibility of evidence, and consequently, all evidence is admissible and the Court is free in assessing the probative value of it. ${ }^{18}$ The Court's established approach is, as held in Armed Activities on the Territory of the Congo (Democratic Republic of the Congo v. Uganda), that it

will identify the documents relied on and make its own clear assessment of their weight, reliability and value. In accordance with its prior practice, the Court will explain what items it should eliminate from further consideration. ${ }^{19}$

See, for instance, UNGA, Fifty-second Session, Report of the International Court of Justice (A/52/4), 27 October 1997, Statement by H.E. Judge Schwebel (“[...] the Court's attitude towards evidence is demonstrably flexible."); Lauterpacht, supra note 4, at 431; Joyce, supra note 4 , at 286.

9 Markus Benzing, “Evidentiary Issues”, in Andreas Zimmermann (ed.), The Statute of the International Court of Justice: A Commentary (2012), 1236.

10 ICJ Statute, Art. 49; ICJ Rules of Court, Art. 62(1).

11 ICJ Statute, Art. 48.

12 ICJ Statute, Art. 5O; ICJ Rules of Court, Art. 62(2).

13 ICJ Statute, Art. 51.

14 Ibid., Art. 66.

15 Ibid., Art. 52; ICJ Rules of Court, Art. 56; Practice Direction IX.

16 ICJ Rules of Court, Art. 50; Practice Direction III.

17 ICJ Statute, Art. 30(1).

18 Military and Paramilitary Activities in and against Nicaragua (Nicaragua v. United States of America), Merits, Judgment, I.C.J. Reports 1986, p. 14, para. 6o; Riddell and Plant, supra note 6, at 152; James Gerard Devaney, Fact-finding before the International Court of Justice (2016), 35-36.

19 Armed Activities on the Territory of the Congo (Democratic Republic of the Congo v. Uganda), Judgment, I.C.J. Reports 2005, para. 59. 
Several scholars have suggested that this lack of evidentiary rules exists for good reason. For some it is the diplomatic sensitivity of having to reject evidence proffered by a sovereign that warrants evidentiary freedom for courts, ${ }^{20}$ while others argue that, in international adjudication, the free appreciation of evidence used to establish a fact plays a crucial role - more than in the national context. ${ }^{21}$

The lack of rules on admissibility is, however, not a problem in all fields of international law. ${ }^{22}$ Clearer guidelines exist in the context of international human rights law and international criminal law. However, it is important to note that these specialized tribunals are confronted with a different set of parties: The admissibility of illegally obtained evidence in international human rights law (similar to criminal law), for instance, requires a balancing between the interests of an individual in the protection of his or her fundamental rights (e.g. right to liberty, right to a fair trial) vis-à-vis the powerful apparatus of a sovereign state. There is, however, considerable doubt as to whether this rationale is equally appropriate to justify stricter admissibility rules for inter-state disputes, where no individual rights are usually at stake, and the two parties are - at least in the eyes of the law - equal. ${ }^{23}$ With these differences in mind, the following section will review sources of international law that potentially regulate the treatment of unlawfully acquired evidence.

\subsection{Rules of International Criminal Courts and Tribunals}

In the procedural framework of international criminal courts and tribunals, the problem of unlawfully obtained evidence is addressed quite prominently. Article 69(7) of the Rome Statute, for instance, stipulates that the International Criminal Court shall not deem evidence admissible that was "obtained by

$20 \quad$ Charles N. Brower, "The Anatomy of Fact-Finding Before International Tribunals: An Analysis and a Proposal Concerning the Evaluation of Evidence", in R.B. Lillich (ed.), Fact-Finding before International Tribunals (1991), 148.

21 Mojtaba Kazazi, Burden of Proof and Related Issues: A Study on Evidence Before International Tribunals (1996), 208; Malcolm N. Shaw, Rosenne's Law and Practice of the International Court: 1920-2015 (Vol. 3), para. 257.

22 See, for instance, on international criminal courts: Vladimir Tochilovsky, Jurisprudence of the International Criminal Courts and the European Court of Human Rights: Procedure and Evidence (2007), 762; Petra Viebig, Illicitly Obtained Evidence at the International Criminal Court (2016), 65 .

23 Marco Roscini, "Digital Evidence as a Means of Proof before the International Court of Justice", 21(3) Journal of Conflict \& Security Law (2016), 553. 
means of a violation of this Statute or internationally recognized human rights" if: ${ }^{24}$

(a) The violation casts substantial doubt on the reliability of the evidence; or

(b) The admission of the evidence would be antithetical to and would seriously damage the integrity of the proceedings. ${ }^{25}$

The Rules of Procedure of the International Criminal Tribunal for the Former Yugoslavia (ICTY) and of the International Criminal Tribunal for Rwanda (ICTR) contain a similarly worded provision in Rule 95, except that it does not specify the law that must be violated in the obtaining of the evidence. ${ }^{26} \mathrm{In}$ addition to these mandatory exclusion rules, Article 89(D) of the ICTY Rules grants a discretionary power to exclude evidence if "its probative value is substantially outweighed by the need to ensure a fair trial." ${ }^{27}$ The same approach is reflected in the Rules of the Special Tribunal for Lebanon (STL), which contain similar mandatory and discretionary exclusion rules. Rule 162 stipulates the same threshold for mandatory exclusion as that contained in the ICTY and ICTR Rules, and adds that "in particular, evidence shall be excluded if it has been obtained in violation of international standards on human rights, including the prohibition of torture."28

The common approach of these evidentiary rules is therefore to prescribe exclusion of evidence if it meets heightened threshold requirements related to reliability or the integrity of the proceedings. Additionally, the ICTY's discretionary rule requires that decisions on exclusion be taken through a balancing test.

\subsection{The Convention against Torture}

In the context of treaties, prohibitions of illegally obtained evidence also come within the realm of protecting individual rights, specifically the protection

24 Viebig, supra note 22, at 106; Wojciech Jasiński, "Admissibility of Illegally Obtained Evidence in Proceedings before International Criminal Courts", in B. Krzan (ed.), Prosecuting International Crimes: A Multidisciplinary Approach (2016), 201-202.

25 Rome Statute of the International Criminal Court, 17 July 1998, UN Doc. A/CONF.183/9, Art. 69(7); Viebig, supra note 22, at 106.

26 Rules of Procedure and Evidence of the International Criminal Tribunal for the former Yugoslavia (Revision 50), 8 July 2015, Rule 95.

27 Ibid., Rule 89(D).

28 Rules of Procedure and Evidence, Special Tribunal for Lebanon, 10 April 2019 (Revision 10), Rule 162 . 
from the use of torture. ${ }^{29}$ Article 15 of the Convention against Torture (СAT) stipulates:

Each State Party shall ensure that any statement which is established to have been made as a result of torture shall not be invoked as evidence in any proceedings, except against a person accused of torture as evidence that the statement was made. ${ }^{30}$

The inadmissibility of evidence obtained through the use of torture is, on the one hand, based on the conclusion that some degree of unreliability will always attach to such evidence. ${ }^{31}$ On the other hand, the prime purpose of torture is often to elicit information or confessions for use in judicial proceedings. The rule therefore also has a purpose of deterring such conduct in evidence collection, ${ }^{32}$ an objective that should arguably apply to inter-state proceedings too. Not only the purpose of the rule, but also its specific content, may become pertinent in the inter-state context, for instance, when a state exercises diplomatic protection over an individual that was subject to a forced confession by authorities of another state. The recently decided Jadhav (India v. Pakistan) case appeared to have involved several confessional statements made by an Indian national during detention in Pakistan. ${ }^{33}$ While it was emphasized that the circumstances of these confessions remained "unknown to the Court",34 and the confessions ultimately had no bearing on the legal question decided by the Court (namely Pakistan's violations of consular notification and access requirements), some doubt arose as to their veracity. ${ }^{35}$ More interestingly, India had in fact requested as a remedy for Pakistan's violations that the Court "direct a trial under ordinary law before civilian courts, after excluding Mr. Jadhav's confession [...]."36

29 See Manfred Nowak and Elizabeth McArthur, The United Nations Convention Against Torture: A Commentary (2008), 503; Tobias Thienel, "The Admissibility of Evidence Obtained by Torture under International Law", 17(2) European Journal of International Law (2006), 35 .

30 UN General Assembly, Convention Against Torture and Other Cruel, Inhuman or Degrading Treatment or Punishment, 10 December 1984, UnTs Vol. 1465, p. 85.

31 Nowak and McArthur, supra note 29, at 504; Dana Baldinger, Vertical Judicial Dialogues in Asylum Cases (2015), 162.

32 Nowak and McArthur, supra note 29, at 504.

33 Jadhav (India v. Pakistan), Judgment of 17 July 2019, I.C.J. Reports 2019, paras. 22, 24, 31.

34 Ibid., paras. 22, 31.

35 Jadhav, supra note 33, Declaration by Judge Sebutinde, p. 5, para. 11 ("While the veracity of this confessional statement and the means by which it was obtained are in dispute [...]").

36 Jadhav, supra note 33, para. 125 . 
The evidentiary rules for torture also raise two implications relevant for the general discussion: First, the deterring purpose of Article 15 CAT raises the question whether a difference in treatment is warranted between evidence that was obtained in the course of an unlawful act directed precisely at obtaining the evidence, or obtained incidental to an independent unlawful act. ${ }^{37}$ The inquiry appears particularly relevant with respect to exclusions of evidence based on principles such as good faith or clean hands (see infra, 3.2 and 3.5). Second, the addition of Article 15 to this international treaty appears to confirm the view of some that exclusion of evidence should be absolute when it was obtained in violation of ius cogens. ${ }^{38}$ These conceptual issues have, among others, been implicated in the practice of international courts and tribunals when dealing with unlawfully obtained evidence, as will be discussed below.

\section{$3 \quad$ Guiding Principles in the Practice of International Courts and Tribunals}

Although most international judicial bodies are not bound by a formal rule of stare decisis, past precedent on procedural questions has had significant normative impact on their approach to procedural issues, to an extent that it served as the main legal authority for such decisions alongside general principles of law. ${ }^{39}$ In its decisions on evidence, the ICJ often relied on its own jurisprudence constante as "normatively relevant". ${ }^{40}$ So far, the submission of illegally obtained evidence has been addressed in only a limited number of international cases, which nevertheless allow some conclusions as to the legal bases considered when faced with a decision to exclude or admit unlawfully obtained evidence. While some of these would qualify as general principles of law, others are rather legal guidelines or factors based on which courts and tribunals have considered such evidence. The standards invoked in jurisprudence either involved considerations of the proper administration of justice (see infra, 3.1), the principle of good faith (see infra, 3.2), the probative

37 Hugh Thirlway, "Dilemma or Chimera? Admissibility of Illegally Obtained Evidence in International Adjudication", 78 American Journal of International Law (1984), 631.

38 Benzing, supra note 9, 1381; Wolfrum, supra note 6, at 563, para. 59; Riddell and Plant, supra note 6, at 51; William A. Schabas, The European Convention on Human Rights: A Commentary (2015), 179-180 (generally on the jus cogens status of the prohibition of torture).

39 Riddell and Plant, supra note 6, at 28 and 31.

$40 \quad$ Benzing, supra note 9, at 1237. 
value of the evidence (see infra, 3.3), or a 'public domain' or clean hands exception (see infra, 3.4).

\subsection{The Proper Administration of Justice}

The most prominently cited decision on the subject of unlawfully obtained evidence is the ICJ's judgment in Corfu Channel. It triggered a controversial debate on the existence of and the need for an 'exclusionary rule' in international law. In Corfu Channel, the United Kingdom had conducted a minesweeping operation in Albanian territorial waters after mines struck two of its vessels, and it argued that the operation was justified by its right to "secure possession of evidence in the territory of another State, in order to submit it to an international tribunal and thus facilitate its task." ${ }^{\prime 1}$ The ICJ found that the United Kingdom had violated Albania's territorial sovereignty through the operation, and clearly rejected the argument purporting a right to 'discovery by intervention' 42 in its judgment:

Intervention is perhaps still less admissible in the particular form it would take here; for, from the nature of things, it would be reserved for the most powerful States, and might easily lead to perverting the administration of international justice itself. ${ }^{43}$

The legal standard that, in the Court's view, such evidentiary practice could run afoul of appears to be the principle of the proper or sound administration of justice. The Court has referred to the principle when explaining many of its procedural decisions, such as the inadmissibility of additional claims during the proceedings, ${ }^{44}$ the joinder of proceedings, ${ }^{45}$ the removal of a case

41 "According to [the U.K.], the corpora delicti must be secured as quickly as possible, for fear they should be taken away, without leaving traces, by the authors of the minelaying or by the Albanian authorities. [...] It was presented first as a new and special application of the theory of intervention, by means of which the State intervening would secure possession of evidence in the territory of another State, in order to submit it to an international tribunal and thus facilitate its task." Corfu Channel case (United Kingdom of Great Britain and Northern Ireland v. Albania), Judgment of April gth 1949, I.C.J. Reports 1949, p. 4, at p. 34. Nasim Hasan Shah, "Discovery by Intervention: The Right of a State to Seize Evidence Located within the Territory", 53(3) American Journal of International Law (1959), 612.

43 Corfu Channel, supra note 41, at 35 .

44 Ahmadou Sadio Diallo (Republic of Guinea v. Democratic Republic of the Congo), Merits, Judgment, I.C.J. Reports 2010, p. 639, paras. 38-39.

45 Certain Activities Carried Out by Nicaragua in the Border Area (Costa Rica v. Nicaragua), Joinder of Proceedings, Order of 17 April 2013, I.C.J. Reports 2013, p. 166, para. 24. 
from the General List due to a manifest lack of jurisdiction, ${ }^{46}$ the conduct of proceedings after non-appearance of a party, ${ }^{47}$ and the invocation by a party of a new jurisdictional basis. ${ }^{48}$ The principle of the equality of the parties, too, is reflected in this practice, and appears intrinsically linked to the proper administration of justice, as it guarantees that each party receives the same opportunity to present its case to the Court, and thereby ensures that neither party is granted an unfair advantage over the other. ${ }^{49}$

Despite the Court's strong rejection of violations of law for the purpose of obtaining evidence, and the reference to a legal standard applicable to international proceedings, the ICJ was not as clear on the consequences that should apply to the evidence itself. In fact, other than in the above-cited passage, the ICJ's rejection of unlawful discovery found no reflection in its judgment: The Court did not discuss the issue of admissibility of the evidence gained through the territorial intrusion at all and ultimately even used some of the evidence obtained in the unlawful minesweeping mission to corroborate a violation of international law by Albania. ${ }^{50}$ Corfu Channel was the first and only concluded case to date in which the ICJ could have pronounced itself on illegally obtained evidence (see infra, 3.5 for a discontinued case). The ambiguity between the Court's rejection of the United Kingdom's argument and the concurrent admission of the evidence has left much confusion on the status of such evidence.

The more widespread interpretation in the subsequent debate ${ }^{51}$ is that, as the Court did not discuss the admissibility of such evidence in Corfu Channel,

46 Armed Activities on the Territory of the Congo (New Application: 2002) (Democratic Republic of the Congo v. Rwanda), Jurisdiction and Admissibility, Judgment, I.C.J. Reports 2006, p. 6, para. 25 .

47 Military and Paramilitary Activities in and against Nicaragua (Nicaragua v. United States of America), Merits, Judgment, I.C.J. Reports 1986, p. 14, para. 31.

48 Legality of Use of Force (Yugoslavia v. Belgium), Provisional Measures, Order of 2 June 1999, I.C.J. Reports 1999, p. 124, para. 44.

49 Shaw, supra note 21 , para. $25^{8}$.

50 The U.K. had taken two mines from the minefield during "Operation Retail", and photographs of these mines were later submitted in Court. Although the Court appointed independent experts to corroborate many of the factual claims, in its questions to the experts, it specifically requested them to determine whether the mines that struck the two vessels were of the same type as the two mines obtained during the unlawful mission, thereby proving that the mines causing the explosion could not have been floating mines as Albania claimed. Corfu Channel, supra note 41, Annex I, List of Documents submitted to the Court, p. 133, points 18-19, and p. 135, point 64; Annex 2, p. 144, Question 2. See also Wolfrum, supra note 6 , at 563 .

$5^{1}$ A minority opinion in the debate was that the ICJ has, by holding that the minesweeping mission violated international law and was not justified by its purpose to secure evidence, 
it also did not establish a general rule on inadmissibility. The view, argued for instance by Thirlway, emphasizes that the ICJ has rather only taken an approach "to discourage self-help in the getting of evidence involving internationally illicit acts" by clearly denouncing the "discovery by intervention" argument. ${ }^{52}$

Although the ICJ has therefore taken a clear stance on unlawful obtaining of evidence in principle, it has not highlighted an appropriate procedural consequence. An inquiry as to why the ICJ did not address the issue of admissibility may properly start with the important fact that Albania never challenged it. ${ }^{53}$ Authors of the time already suggested that the Court could have excluded the evidence by drawing analogies to national systems. ${ }^{54}$ In retrospect, and with knowledge of the subsequent procedural practice of the Court, excluding the evidence based on the principle of the proper administration of justice would not appear to be an unconventional move.

One could also argue that the ICJ may well have considered inadmissibility, but decided against it by weighing the territorial intrusion against the clarification of exceptionally dangerous circumstances involving mines in international waters. If that were the - legitimate - motivation of the decision, mentioning these considerations would have furthered the development of a transparent 'balancing of interests' test when dealing with such evidence. However, it is not uncommon for decisions of the Court on evidentiary matters to refrain from naming the standards that are applied, a fact that former ICJ President Judge Rosalyn Higgins has called a "reluctance to be specific" with respect to the standard of proof. ${ }^{55}$ Nevertheless, the factual background of Corfu Channel allows the inference that comparing the gravity of the intrusion in the obtaining of the evidence to the gravity of the international wrong to be proven, may serve as a useful factor in a potential balancing test (see infra, 5).

established a rule on inadmissibility of illegally obtained evidence. The (unconvincing) argument finds that Corfu Channel both establishes a rule of inadmissibility, and against the background that the evidence was still admitted in this case, represents an exception to the rule at the same time. The Court has exceptionally tolerated, "by special jurisprudence", violations of international law for the special circumstances at issue. See Michael Reisman and Eric Freedman, "The Plaintiff's Dilemma: Illegally Obtained Evidence and Admissibility in International Adjudication", 76 American Journal of International Law (1982), 747 .

$5^{2}$ Thirlway, supra note 37 , at 641 .

53 Benzing, supra note 9, at 1243; Shah, supra note 42, at 607 .

54 Shah, supra note 42 , at 607 .

55 Speech by H.E. Judge Rosalyn Higgins, President of the International Court of Justice, to the Sixth Committee of the UN General Assembly (2 November 2007), 4-5. 


\section{2}

\section{The Principle of Good Faith}

The well-established general principle of good faith has generally been considered to instruct states to adhere to "trust, honesty, conscientiousness, and loyalty" in the conduct of international obligations. ${ }^{56}$ Although "not in itself a source of obligation where none would otherwise exist", 57 in the context of procedural law, the principle has evolved to provide very specific "concretizations" in the form of procedural sub-principles, such as the prohibition of abuse of rights in proceedings, or the principle of estoppel..$^{58}$ General principles of law are often viewed as necessary 'gap-fillers' complementing customary and conventional law. ${ }^{59}$ Kolb writes that, when a state's conduct infringes on another state's legitimate interests, but no international norm prohibits this conduct, "there is a possibility of looking at the matter through the lens" of the principle of good faith, ${ }^{60}$ especially in respect of legal proceedings. ${ }^{61}$

The specific value of the principle of good faith in the context of admissibility of evidence was recognized in the Methanex v. United States arbitration, where the tribunal was faced with evidence obtained through trespass. The respondent challenged the introduction into evidence of documents which were allegedly copied illegally from private files of a witness and his company. ${ }^{62}$ The tribunal indeed excluded the evidence, which it confirmed as having been obtained by "deliberately trespassing onto private property and rummaging through dumpsters inside the office-building for other persons' documentation." ${ }^{63}$ The decision was predominantly based on the duty to act in good faith, which the tribunal saw reflected in the applicable UNCITRAL Arbitration Rules: ${ }^{6}$

$5^{6}$ Markus Kotzur, "Good Faith (Bona fide)", in R. Wolfrum (ed.), Max Planck Encyclopedia of Public International Law (2012), 514; Nuclear Tests (Australia v. France), Judgment, I.C.J. Reports 1974, para. 46 ("One of the basic principles governing the creation and performance of legal obligations, whatever their source, is the principle of good faith. Trust and confidence are inherent in international co-operation $\left.[\ldots . . .]^{\prime \prime}\right)$. Border and Transborder Armed Actions (Nicaragua v. Honduras), Jurisdiction and Admissibility, Judgment, I.C.J. Reports 1988, para. 94.

$5^{8}$ Kotzur, supra note 56, at 514; Robert Kolb, Good Faith in International Law (2017), 23; see similarly in wто dispute settlement: Michelle T. Grando, Evidence, Proof, and Fact-Finding in WTO Dispute Settlement (2009), 36.

59 Shaw, supra note 21, para. 376.

6 o Kolb, supra note 58 , at 6.

61 Ibid., p. 255.

62 Methanex Corporation v. United States of America, UnCITRAL, Final Award of 3 August 2005, Part II, Chapter I, para. 2.

63 Ibid., para. 55 .

64 Article 15(1) of the then applicable version of the UnCitral Arbitration Rules gave the tribunal the power to "conduct the arbitration in such manner as it considers appropriate, 
[...] the Disputing Parties each owed in this arbitration a general legal duty to the other and to the Tribunal to conduct themselves in good faith during these arbitration proceedings and to respect the equality of arms between them, the principles of 'equal treatment' and procedural fairness being also required by Article 15(1) of the UNCITRAL Rules. As a general principle, therefore, just as it would be wrong for the USA ex hypothesi to misuse its intelligence assets to spy on Methanex (and its witnesses) and to introduce into evidence the resulting materials into this arbitration, so too would it be wrong for Methanex to introduce evidential materials obtained by Methanex unlawfully. ${ }^{65}$

In its analysis, the tribunal considered a number of factors, such as whether the deliberate trespassing onto private property and searching of trash violated national laws, and whether the evidence was of great significance or whether it could be substituted. ${ }^{66}$ The tribunal concluded that the "documentation was procured by Methanex unlawfully" and must be excluded pursuant to the "general duty of good faith imposed by the UNCITRAL Rules". ${ }^{67}$

The Methanex award confirmed the relevance of the principle of good faith for the problem of illegally obtained evidence, and other investment tribunals seem to have followed suit. In $E D F$ v. Romania, the tribunal excluded an audiotape, meant to prove an allegation of corruption, primarily on the basis of a lack of authenticity (see also infra, 3.3). ${ }^{68}$ However, it also appeared to have considered the "unlawful creation" of the evidence in its decision to exclude it. In particular, it did so with reference to the principle of good faith:

Admitting the evidence represented by the audio recording of the conversation held in Ms. Jacob's home, without her consent in breach of her right to privacy, would be contrary to the principles of good faith and fair dealing required in international arbitration. In that regard, the Tribunal shares the position of the Methanex award. ${ }^{69}$

provided that the parties are treated with equality and that at any stage of the proceedings each party is given a full opportunity of presenting his case." UNCITRAL Arbitration Rules (1976), UN Doc. A/RES/31/98, Art. 15(1).

65 Methanex, supra note 62, para. 54.

66 Ibid., paras. $55^{-56}$.

$67 \quad$ Ibid., para. 58 .

68 Emily Sipiorski, "Evidence and the Principle of Good Faith in Investment Arbitration: Finding Meaning in Public International Law", in D. Moura Vicente (ed.), Towards a Universal Justice? Putting International Courts and Jurisdictions into Perspective (2016), 361.

69 EDF (Services) Limited v. Romania, ICSID Case No. ARB/05/13, Procedural Order No. 3, 29 August 2008, para. 38 . 
Even if not an obligation of result, the nature of good faith as an obligation of conduct seems to require - at least in the eyes of investment tribunals some reflection in a rule on admissibility. Although some may question the relevance of such investment arbitration 'precedent' for state-to-state proceedings based on the need to cure the relative inequality of parties in investment proceedings, such doubts may be dissipated when considering the fact that, in both Methanex and $E D F$, it was the investor who introduced unlawfully obtained evidence into the record.

\subsection{The Probative Value of the Evidence}

In the seven decades that have passed since Corfu Channel, old issues remained unresolved, and more challenging factual scenarios have been added to the discussion. One that merits special attention is the problem of 'WikiLeaks documents'. In November 2010, the online platform WikiLeaks published around 250,000 confidential diplomatic cables from 274 embassies, consulates and missions of the United States, which were leaked by a member of the United States Army. ${ }^{70}$ Leaked documents may per se not be considered evidence obtained in violation of international law, as there is no rule of international law prohibiting acts of whistle-blowing. ${ }^{71}$ The dissemination of such classified information may violate national laws, such as, in the case of the United States, the Espionage Act of 1917 or possibly also U.S. criminal law. ${ }^{72}$ As is well-known, illegality under national laws will not automatically translate into an international wrong, ${ }^{73}$ although some appear to suggest otherwise in

70 James H. Boykin and Malik Havalic, "Fruits of the Poisonous Tree: The Admissibility of Unlawfully Obtained Evidence in International Arbitration”, 12(5) Transnational Dispute Management (2015), 1.

71 William T. Worster, "The Effect of Leaked Information on the Rules of International Law", 28(2) American University International Law Review (2013), 447.

72 See Chelsea Manning's conviction under, inter alia, the Espionage Act and Julian Assange's recent indictment for conspiracy to commit computer hacking: United States v. Manning, 78 M.J. 501 (United States Army Court of Criminal Appeals 2018), p. 506; "Julian Assange Arrested in London as U.S. Unseals Hacking Conspiracy Indictment", 11 April 2019, New York Times, available at https://www.nytimes.com/2019/o4/11/world/europe/julian -assange-wikileaks-ecuador-embassy.html?modul e=inline; Philipp Janig, "Julian's Golden Cage: Julian Assange, the UN Working Group on Arbitrary Detention and the Quest for Scholarly Diligence - A Case Study", 18 Austrian Review of International and European Law (2016), 18, 21.

73 On the irrelevance of domestic law for international responsibility, see: International Law Commission, Draft Articles on Responsibility of States for Internationally Wrongful Acts, 2001, UN Doc. A/56/10, Art. 3. 
relation to investment arbitration..$^{74}$ In any case, the use of WikiLeaks evidence in international judicial proceedings is on the rise, as a recent decision of the Special Tribunal for Lebanon demonstrates. ${ }^{75}$

In Ayyash et al., four individuals faced trial in relation to the 2005 attack in Beirut that killed former Lebanese Prime Minister Rafik Hariri and 21 others. In 2015, the STL issued its "Decision on the Admissibility of Documents Published on the WikiLeaks Website" dealing with two purported diplomatic cables from WikiLeaks, describing meetings between Lebanese politicians and a U.S. ambassador. ${ }^{76}$ The sTL dealt with the leaked documents under the realm of reliability rather than illegality, and extensively discussed whether it should exclude the evidence pursuant to Rule 149(D), which allows for discretionary exclusion if the "probative value is substantially outweighed by the need to ensure a fair trial." ${ }^{77}$ It first analyzed identical rules applied in ICC and ICTY cases and concluded that, for its decision on admissibility, the trial chamber will "assess the authenticity of the WikiLeaks documents based on whether a document is what it professes to be in origin and authorship". ${ }^{78} \mathrm{In}$ its analysis, it reviewed cases from international and domestic courts where WikiLeaks documents had been considered, and concluded that the "judicial trend is therefore not, as argued [...], towards admitting WikiLeaks documents into evidence." ${ }^{79}$ In these circumstances, it held that the documents did not "have the necessary prima facie indicia of reliability - namely, authenticity and accuracy - for admission into evidence." 80 The question whether the evidence should be excluded based on illegality pursuant to Rule 162 was only briefly flagged by the prosecution, and the tribunal considered the question

74 In the arbitrations between Yukos shareholders and Russia, the tribunal relied on WikiLeaks documents, but did not address the question of admissibility of such evidence at all. Boykin and Havalic found it to be "surprising" that an international arbitral tribunal decided to rely on this type of evidence, as "it is beyond dispute that Private Manning's disclosure of the cables was illegal under United States law." Boykin and Havalic, supra note 70 , at 4.

75 Ayyash et al., Case No. STL-11-01/T/TC, ICL 1051, Special Tribunal for Lebanon, Decision on the admissibility of documents published on WikiLeaks website, 21 May 2015.

$76 \quad$ Ibid., para. 1.

77 STL Rules, supra note 28, Rule 149(D).

78 Ayyash et al., supra note 75, para. 13; Prlić et al., ICTY, Case No. IT-04-74-AR73.16, Decision on Jadranko Prlić's Interlocutory Appeal against the Decision on Prlić Defence Motion for Reconsideration of the Decision on Admission of Documentary Evidence, 3 November 2009, paras. 33-34.

79 Ayyash et al., supra note 75, para. 42.

8 o Ibid., paras. $34^{-35}$. 
redundant as it has already decided the issue based on the evidence's probative value. ${ }^{81}$

The tribunal's exclusion of the leaks based on their (lack of) probative value reveals a potential alternative to exclusion based on illegality. In the specific context of WikiLeaks documents, however, the doubts as to their probative value or veracity was to some extent contradicted by an arbitrator in ConocoPhillips v. Venezuela. ${ }^{82}$ After the tribunal issued its Decision on Jurisdiction and Merits in 2013, the respondent submitted a number of WikiLeaks cables describing how representatives of the investor briefed the U.S. ambassador in Caracas on compensation negotiations with Venezuela. However, the tribunal rejected the respondent's request to reconsider the 2013 Decision due to lack of authority, and arbitrator Georges Abi-Saab emphasized in his dissent that

the revelations of Wikileaks cables change the situation radically in dimension and seriousness. Here we have a full narrative of the negotiations, with a high degree of credibility, given the level of detail that tallies perfectly with what we know of the rest of the record. It is a narrative that radically confutes the one reconstructed by the Majority $[\ldots] .^{83}$

In a subsequent Interim Decision of 2017, the tribunal rejected the view that the WikiLeaks cables were sufficient proof for Venezuela's allegation that it did make an offer for compensation based on fair market value. ${ }^{84}$ However, the tribunal did not address the nature or origin of the WikiLeaks cables in its reasoning, and simply appeared to argue that Venezuela neither proffered witness statements nor documentary evidence capable of proving the alleged fact. The dissenting opinion as well as the argumentation in the Interim Decision seem to look at the issue of the cables' probative value from two angles: While arbitrator Georges Abi-Saab considers them to possess "a high degree of credibility", the tribunal did not find them equally compelling as other forms of evidence. Nevertheless, both Ayyash and ConocoPhillips appear to have regarded the cables' probative weight as a deciding factor.

81 "As the Trial Chamber has decided the issue on the documents' probative value, it need not consider this." Ibid., para. 44.

82 ConocoPhillips Petrozuata B.V., ConocoPhillips Hamaca B.V. and ConocoPhillips Gulf of Paria B.V.v. Bolivarian Republic of Venezuela, ICsid Case No. ARB/o7/3o.

83 ConocoPhillips Petrozuata B.V., ConocoPhillips Hamaca B.V. and ConocoPhillips Gulf of Paria B.V. v. Bolivarian Republic of Venezuela, ICsID Case No. ARB/o7/30, Dissenting Opinion of Georges Abi-Saab (Decision on Jurisdiction and Merits dated 3 September 2013), p. 23.

84 ConocoPhillips v. Venezuela, Interim Decision dated 17 January 2017, p. 48, para. 135. 
There is, arguably, a strategic dilemma inherent in the choice of whether to plead illegality or unreliability for counsel attempting to effect the exclusion of a document. If the state from whose archives, for instance, the evidence was stolen or leaked claims exclusion based on illegality, this may come close to an implicit confirmation of the authenticity of the documents (because, in fact, state facilities are claimed to be their origin).

\subsection{The 'Public Domain' Exception and Clean Hands}

An important conceptual question arising in some cases is whether it is relevant who obtained the evidence unlawfully and who is using it in court. This question deserves attention in light of two situations. The first would be one where information was obtained illegally by someone, put into the public domain, and subsequently used by an uninvolved party in proceedings. The second situation relevant to this inquiry would be where the evidence was, although not in the public domain, nevertheless obtained by someone other than the party using it. While the former scenario may implicate considerations of a 'public domain exception', the latter is arguably relevant against the background of the 'clean hands doctrine'. Two cases before, respectively, the European Court of Justice (ECJ) and the English Court of Appeal may be highlighted in this regard.

In Persia International Bank PLC v. Council of the European Union, the ECJ ruled in favor of admitting diplomatic cables submitted by the applicant which originated from WikiLeaks. The Court reasoned that the "possibly unlawful nature" of the disclosed diplomatic cables could not be held against the applicant who had not been involved in their disclosure. ${ }^{85}$ The English Court of Appeal reached a similar conclusion when faced with WikiLeaks documents in Bancoult III. The evidence was challenged based on the inviolability of the documents under Articles 24 and 27, paragraph 2, of the Vienna Convention on Diplomatic Relations (VCDR), and the English Court of Appeal confirmed in principle that such inviolability "extends to make it impermissible to use such documents or copies in a domestic court of the host country." ${ }^{86}$ However, for such evidence to be excluded based on their inviolability, the contents of the document must, inter alia, not have become "so widely disseminated in the public domain as to destroy any confidentiality or inviolability that could

85 Persia International Bank PLC v. Council of the European Union, Case T-493/10, Judgment of the General Court (Fourth Chamber), 6 September 2013, para. 95.

$86 R$ (on the application of Bancoult No. 3) (Appellant) v. Secretary of State for Foreign and Commonwealth Affairs (Respondent), Judgment of 8 February 2018, para. 20. 
sensibly attach to it." 87 The condition was not fulfilled in the case at issue, and the Court held that

[i]n the present case, the cable has been put into the public domain by the Wikileaks publication and the newspaper articles which followed, in circumstances for which the appellant has no responsibility. In my opinion, the cable has as a result lost its inviolability $[\ldots] .{ }^{88}$

Based on the case law of both the ECJ and the English Court of Appeal, it therefore appears not established that the unlawfulness remains inherent in the evidence when used by a third, uninvolved party. ${ }^{89}$ This conclusion would support the relevance of another general principle in this context, the principle of ex iniuria ius non oritur. Accordingly, it could be argued that evidence obtained through breaches of international law constitutes a wrong-doing from which the responsible party should not be able to take advantage or receive rights. ${ }^{90}$ Amerasinghe already argued that:

The answer perhaps lies in approaching each case on its merits with a possible presumption, based on the general principles that no one should benefit from his own wrong-doing and that no right can arise from a wrong, that evidence obtained in violation of international law is in principle inadmissible. ${ }^{91}$

The relevance of the principle may, however, be weakened in cases where the unlawfully acquired evidence was obtained without the involvement of the party introducing it, as the right or advantage must be acquired by the wrongdoer himself in order to invoke these principles. ${ }^{92}$ Good faith, on the

\footnotetext{
$87 \quad$ Ibid.

88 Ibid., para. 21.

89 For an earlier case related to this discussion, see Rose v. The King: The case is an example of a situation in which the party using the evidence, here the Canadian government, was not the one to unlawfully seize it. The court ultimately deemed the evidence (documents from the Soviet embassy) admissible, but not by addressing the question of unlawful acquisition of evidence and rather by rejecting that the documents from diplomatic premises enjoyed inviolability because the Soviet government never claimed such privilege for them. William W. Bishop, "Rose v. The King. [1947]", 42(2) American Journal of International Law (1948), 945-947.

$90 \quad$ Kazazi, supra note 21, at 206.

91 Chittharanjan F. Amerasinghe, Evidence in International Litigation (2005), 179.

92 Worster, supra note 71 , at 447.
} 
other hand, appears to be a potential 'catch-all basis' for the many scenarios in which illegally obtained evidence can make its way to a court or tribunal.

\subsection{Conclusion: Not One Rule, but Many Principles}

This review of pertinent cases reveals two things: First, the lack of a generally binding rule on the admissibility of unlawfully obtained evidence and the dire need for clearer rules as similar incidents are increasing. In 2013, for instance, the ICJ was seized with Questions relating to the Seizure and Detention of Certain Documents and Data (Timor-Leste v. Australia), a case in which Timor-Leste contended that documents were apprehended by Australian agents in the offices of one of its legal advisers that included correspondence with the Government of Timor-Leste relating to a pending arbitration between the two states. ${ }^{93}$ Although the Court ultimately did not have to rule on the question as the materials were returned and the case was discontinued, ${ }^{94}$ it is curious what such a factual scenario could bring for the law on unlawfully acquired evidence.

The second revelation the discussion of case law has brought is that, despite the need for regulation in this area, the cases discussed afford some clarification as to potential legal grounds for excluding unlawfully obtained evidence and common factors considered by judicial bodies in their dealings with it. Corfu Channel, Methanex and EDF illustrate the significance of general principles of law for decisions on the admissibility of such evidence, particularly the principle of good faith. At the same time, Persia International Bank and Bancoult III demonstrate requirements as to the link between the person setting the wrongful act, and the party using the resulting evidence in court, making way for a potential exception for publicly available information. Lastly, an alternative avenue to exclude such evidence could be in assessing its probative value, as shown in Ayyash.

The cases have also elucidated that some sort of 'balancing of interests' will be necessary within each of these potential legal bases to exclude such evidence. For the purpose of identifying elements to be weighed in such a test, the criteria considered by the cases above may appear useful. These are, in particular, the gravity of the violation to obtain the evidence compared to the gravity of the wrong for which it is used as proof (Corfu Channel); whether the probative value of it (its reliability, authenticity and accuracy) substantially outweighs the need to ensure a fair trial (Ayyash et al.); whether the evidence

93 Questions relating to the Seizure and Detention of Certain Documents and Data (Timor-Leste v. Australia), Application Instituting Proceedings by Timor-Leste, 17 December 2013.

Ibid., Order of 11 June 2015, I.C.J. Reports 2015, p. 572. 
was obtained in the course of an unlawful act directed precisely at obtaining the evidence, or whether it was obtained incidental to an independent unlawful act (Corfu Channel, Methanex); whether the evidence was of marginal significance or could be substituted by other evidentiary material (Methanex); and whether the party putting forth the evidence in judicial proceedings was materially involved in the unlawful obtaining of the evidence (Methanex, Persia International Bank, Bancoult III). These factors shall be considered in more detail in the concluding discussion on a potential balancing test (see infra, 5), together with legal implications derived from national systems.

\section{Deriving a General Principle from National Laws? - A Comparative} Study of National Civil Procedure

As already briefly discussed in the context of the principle of good faith (see supra, 3.2), general principles of law have traditionally represented the central source of authority for procedural rules in international law..$^{95}$ Article 38 , paragraph 1(c) of the ICJ Statute lists "general principles of law recognized by civilized nations" as a source of international law to be applied by the Court in cases before it. ${ }^{96}$ For the purposes of determining whether unlawfully obtained evidence should be excluded from international adjudication based on general principles of law, some of the more traditional general principles of law used in international jurisprudence (such as good faith, or ex iniuria ius non oritur) have already been discussed above. The second track of this discussion on general principles examines whether a general principle of inadmissibility of illegally obtained evidence may be derived from domestic legislations. The importance of "common-sense principles underlying rules of evidence in domestic law" was recognized in instances where international law did not provide guidance. ${ }^{97}$ In many national jurisdictions, the problem of illegally obtained evidence has not gone unnoted. At the outset, it is important to emphasize two things about this comparative survey.

First, this survey deliberately excludes exclusionary rules in criminal procedure, which are concerned with the protection of the rights of an individual against intrusions by the powerful apparatus of its government. As explained

95 Benzing, supra note 9, 1237.

96 ICJ Statute, Art. 38(1).

97 Lillie S. Kling v. United Mexican States (8 October 1930), Opinion by Commissioner Nielsen, for the Commission, IV RIAA 575, 582; Bin Cheng, General Principles of Law as Applied by International Courts and Tribunals (1953), 308; Amerasinghe, supra note 91, at 167. 
above (see supra, 2), this version of the principle may not be appropriate for use in inter-state cases. This article therefore examines rules and principles of civil procedure (and constitutional laws applicable to civil proceedings) to ascertain whether they regulate the admissibility of illegally obtained evidence. Second, there are obvious limitations to this comparative legal survey, some of which form part of recognized problems in the comparative legal discipline generally. ${ }^{98}$ Apart from the fact that an extensive discussion of the subject would go beyond the constraints of this article, linguistic and accessibility issues make this a non-exhaustive attempt at comparing domestic laws on the matter. However, a representative number of legal systems has been surveyed, providing results that are highly useful in understanding domestic treatment of the issue.

The present comparative study examines 27 national jurisdictions representing all five U.N. Regional Groups. ${ }^{99}$ It looks at legislation and case law, as well as, where available, already existing legal scholarship on the matter. An excellent contribution on European countries that deserves mention is the piece by Nunner-Krautgasser and Anzenberger summarizing aspects of the broader research project "Dimensions of Evidence in European Civil Procedure".100 The two authors categorized jurisdictions into three branches. ${ }^{101}$ These three approaches are also confirmed in the more global setting of the present survey, with one alteration in the form of a fourth category.

The results of the present survey reveal that, in civil cases, the evidence is either (1) generally admissible (nine countries), ${ }^{102}$ (2) generally inadmissible (six countries), ${ }^{103}$ (3) inadmissible if its discovery either violated a constitutional right (four countries), ${ }^{104}$ or (4) inadmissible if a balancing of interests

98 Mark Van Hoecke, "Methodology of Comparative Legal Research", Law and Method (2015), 3-4.

99 This paper covers legislation and case law from Australia, Bulgaria, Bolivia, Brazil, Canada, Chile, China, Croatia, Egypt, France, Germany, Greece, Ireland, Italy, Japan, Kenya, Malaysia, Nigeria, Peru, Russia, Slovakia, Slovenia, South Africa, Spain, Switzerland, the United Kingdom and the United States. For the UN Regional Groups, see UN Department for General Assembly and Conference Management, "United Nations Regional Groups of Member States", available at https://www.un.org/depts/DGACM/RegionalGroups.shtml. Bettina Nunner-Krautgasser and Philipp Anzenberger, "Inadmissible Evidence: Illegally Obtained Evidence and the Limits of the Judicial Establishment of the Truth", in V. Rijavec, T. Keresteš and T. Ivanc, Dimensions of Evidence in European Civil Procedure (2016), 195-212.

101 Ibid., p. 202.

102 These are: Bulgaria, Canada, Chile, China, Egypt, Japan, Malaysia, the United Kingdom and the United States.

103 These are: Brazil, Croatia, France, Italy, Russia and Slovakia.

104 These are: Greece, Ireland, Peru and Spain. 
favors its exclusion (eight countries). ${ }^{105}$ Among the countries that provide for restrictions on admissibility, nine have legislation in place with explicit rules on the treatment of illegally obtained evidence, ${ }^{106}$ and many more have developed their positions through the judicial interpretation of constitutional or civil procedure provisions. ${ }^{107}$ For the purpose of illustrating the distinct types of national approaches to illegally obtained evidence in civil procedure, some of these national jurisdictions shall be covered in more detail below.

\subsection{Admissibility}

Many of the jurisdictions allowing general admissibility in civil proceedings do in fact limit admissibility in the criminal context. The United States has a long history of viewing the exclusion of evidence as a primary remedy for violations of the Fourth Amendment's protection "against unreasonable searches and seizures". ${ }^{108}$ However, this 'exclusionary rule' is not applicable to civil cases, ${ }^{109}$ and exclusion for purposes of preserving judicial integrity remains a scarce occurrence. ${ }^{110}$ Similarly, as opposed to its criminal procedure, ${ }^{111}$ China's civil procedure legislation does not address illegally obtained evidence. Generally, such evidence will therefore be admissible in civil court. ${ }^{112} \mathrm{~A}$ lack of rules

105 These are: Australia, Bolivia, Germany, Kenya, Nigeria, Slovenia, South Africa and Switzerland.

106 The relevant provisions are:Australia (Art.138 of the National Uniform Legislation Evidence Act); Brazil (Art. 5(56) of the Constitution); Croatia (Art. 29(4) of the Constitution); Greece (Art. 19(3) of the Constitution); Kenya (Art. 5o(4) of the Constitution); Nigeria (Section 14 of the Evidence Act); Russia (Art. 5o(2) of the Constitution); Spain (Art. 287 of Civil Procedure Code); Switzerland (Art. 152(2) of the Civil Procedure Code).

107 E.g. Bolivia, France, Germany, Ireland, Italy, Peru, Slovakia, Slovenia and South Africa.

108 Cynthia Lee, L. Song Richardson and Tamara Lawson, Criminal Procedure: Cases and Materials (2nd edition, 2018), 377; on the federal level: Weeks v. United States, 232 U.S. 383 , 34 S. Ct. 341 (1914); on the state level: Mapp v. Ohio, 367 U.S. 643 (1961).

109 The U.S. District Court for the Eastern District of New York, for instance, confirmed that "the Fourth Amendment's exclusionary rule does not apply in civil actions other than civil forfeiture proceedings." Mejia v. City of N.Y., 119 F. Supp. 2d 232, 254 n.27 (E.D.N.Y. 200o); David Taylor, "Should It Take a Thief?: Rethinking the Admission of Illegally Obtained Evidence in Civil Cases", 22(3) Review of Litigation (2003), 626.

110 Ibid., p. 628.

111 Jingkun Liu, The Exclusionary Rule of Illegal Evidence in China: Theory, Case, Application (2019), 116; Mou Luye, "Atomism or Holism: Evidential Evaluation in China's Exclusionary Rule of Illegally Obtained Evidence", 5(2) Peking University Law Journal (2017), 361, 362.

112 Douglas Clark, Patent Litigation in China (2011), 113-114. 
on such evidence in civil cases further exists in Chile, ${ }^{113}$ Egypt, ${ }^{114}$ Japan, ${ }^{115}$ Malaysia, ${ }^{116}$ and the United Kingdom, ${ }^{117}$ with some of these countries even imposing no restrictions on admissibility of evidence other than relevance.

\subsection{Inadmissibility}

Inadmissibility of illegally obtained evidence in civil cases has proven to be not quite uncommon. The survey has revealed that six countries make inadmissibility the general rule. Brazil's Constitution, for instance, stipulates in Article $5(56)$ that, to ensure fundamental rights, "evidence obtained through illicit means [is] unacceptable in the process."118 Admissibility of such evidence is considered an exceptional occurrence and will only be allowed if certain criteria are met. ${ }^{119}$ Russia, too, regulates the issue in its Constitution, namely in Article $5 \mathrm{O}(2)$, which prohibits, "in administering justice", the "use of evidence received through violating federal law."120 The provision has been subject to quite literal application in civil cases. ${ }^{121}$ France and Italy have also developed, through their jurisprudence, a practice of general inadmissibility: The former, through the principle of loyauté de la preuve or fairness of evidence, ${ }^{122}$ and the latter, through the judicial application of a "deontological approach" to admitting such evidence. ${ }^{123}$

113 Eduardo Jequier Lehuede, "Obtencion Ilicita de la Fuente de la Prueba en el Proceso Civil - Analisis Comparativo del Ordenamiento Juridico Espanol y Chileno”, 34 Revista Chilena de Derecho (2017), 457, 493.

114 Fathi Waly, "Egypt" (2011), in P. Taelman (ed.), International Encyclopaedia of Laws: Civil Procedure, 77 .

115 Akira Ishikawa and Fathi Waly, "Japan" (2008), in P. Taelman (ed.), International Encyclopaedia of Laws: Civil Procedure, 78.

116 Juriah Abd Jalil and Shahrul Mizan Ismail, "Malaysia" (2019), in P. Taelman (ed.), International Encyclopaedia of Laws: Civil Procedure, 129.

117 Nunner-Krautgasser and Anzenberger, supra note 100, at 203.

118 Constitution of the Federative Republic of Brazil, 1988 Constitution (last amended 1996), available at: https://www.wipo.int/edocs/lexdocs/laws/en/br/brinen.pdf.

119 Humberto Dalla Bernardina de Pinho and Renata Berlinski de Brito e Cunha, "Brazil", in P. Taelman (ed.), International Encyclopaedia of Laws: Civil Procedure (2019), 155-156.

120 Constitution of the Russian Federation, 12 December 1993, available at Government of the Russian Federation, http://archive.government.ru/eng/gov/base/54.html.

121 Jane Colston, Olga Bischof, Cameron Moxley and Anna Grishchenkova, "The fruit from a poisoned tree - use of unlawfully obtained evidence", IBA International Litigation Newsletter (September 2017), 23, citing Case No. 33-10295/12, Supreme Court of Republic Bashkortostan, Appeal, 6 September 2012.

122 Martin Oudin, Evidence in Civil Law - France (2015), 44.

123 Vito Breda and Matteo Vricella, "English Pragmatism and Italian Virtue. A Comparative Analysis of the Regime of Illegally Obtained Evidence in Civil Law Proceedings between 


\subsection{Exclusion Conditional upon Constitutional Violations}

The third approach to illegally obtained evidence can be distinguished from the fourth (see infra, 4.2.4) by the fact that, once a violation of constitutional provisions has occurred, the exclusion is "automatic", and no further balancing of interests will be required. A case in point, Spain, demonstrates a strong incorporation of exclusionary rules in its civil procedure. Both Article 11.1 of Law 1/1985 on the Organization of the Judiciary, and Article 287(2) of the Civil Procedure Act, regulate unlawfully obtained evidence. ${ }^{124}$ Article 287 grants the parties the right to challenge evidence obtained by a violation of a fundamental right, ${ }^{125}$ and depending on when the challenge has been brought, the evidence will be excluded or ruled to have no effect. ${ }^{126}$ Similarly, in Ireland, a breach of constitutional rights in the obtaining of evidence will lead to the inadmissibility of such evidence, although some requirements as to deliberateness must be fulfilled. ${ }^{127}$ Besides sound jurisprudence on the issue, ${ }^{128}$ Greece has a constitutional provision, Article 19(3), that explicitly prohibits the "use of evidence acquired in violation of the present article and of articles 9 and $9 \mathrm{~A}^{\prime}{ }^{129}$ The cited articles protect, inter alia, the right to secrecy of correspondence, the inviolability of private and family life, and personal data. The provision has been considered an innovation because it is "constitutional, automatic and absolute." ${ }^{130}$ A similar conditioning upon constitutional violations has occurred in Peru, where illegally obtained evidence is considered to be indirectly regulated in both the Constitution and the Civil Code. ${ }^{131}$

Italy and England", 21 Maastricht Journal of European \& Comparative Law (2014), 428, 436-437.

124 Rafael Bellido Penadés, "La prueba ilícita y su control en el proceso civil", 89 Revista Española de Derecho Constitucional (2010), 77, 78; Núria Mallandrich Miret, Evidence in Civil Law - Spain (2015), 9.

125 Christa M. Madrid Boquín, "The Exclusion of Unconstitutionally Obtained Evidence in Civil Proceedings: A Comparative Analysis between the USA and Spain", 3 Jurnalul de Studii Juridice (2014), 13, 31.

126 Miret, supra note 124, at 10.

127 Bríd Moriarty, Evidence in Civil Law - Ireland (2015), 108-109; Nunner-Krautgasser and Anzenberger, supra note 100, at 205.

128 Athanassios Kaissis, "Exclusion of Illegally Obtained Evidence in Greek Penal and Civil Proceedings", Digesta (2015), 458.

129 Constitution of Greece (1975, amended 2008), Art. 19(3), available at: https://www.wipo .int/ edocs/lexdocs/laws/en/gr/gr22oen.pdf.

130 Dimitrios Giannoulopoulos, "The Exclusion of Improperly Obtained Evidence in Greece: Putting Constitutional Rights First", 11(3) International Journal of Evidence \& Proof (2007), 195 .

131 Art. 199 of the Civil Code (Translation by the author): "Evidence obtained by simulation, fraud, intimidation, violence or bribery shall be devoid of probative effect." (Spanish 
Article 2.10 of the Constitution stipulates that documents and statements obtained in breach of constitutional protections of private communications shall have "no legal effect"132 and the Constitutional Court required that the illegality stem from a violation of constitutional laws or fundamental rights and not of laws of inferior rank. ${ }^{133}$

\subsection{Exclusion Conditional upon a Balance of Interests}

The most widespread approach among jurisdictions regulating illegally obtained evidence is to deem such evidence inadmissible if a balance of interests weighs in favor of exclusion. The different variations of this 'balance of interests' test share common criteria.

An elaborate example of a balancing test for unlawfully acquired evidence is found in Australia's National Uniform Legislation Evidence Act. Section 138, applicable to both criminal and civil proceedings, ${ }^{134}$ stipulates that evidence obtained through an impropriety, ${ }^{135}$ or a contravention of Australian law shall not be admitted, unless, in light of the way in which the evidence was obtained, "the desirability of admitting the evidence outweighs the undesirability of admitting the evidence." ${ }^{136}$ The elaborate (and better formulated) part of the provision, paragraph 3 , includes a non-exhaustive list of factors that may be considered for the "desirability" test, such as the nature of the cause

original: "Carece de eficacia probatoria la prueba obtenida por simulación, dolo, intimidación, violencia o soborno."). See Codigo Procesal Civil, Ministerial Resolution No. 10-93-JUS, Enacted 8 January 1991, Art. 199, available at: https://iberred.org/sites/default/ files/codigo-procesal-civil-per3.pdf. Javier Villa Garcíaio, "La Prueba Prohibida en el Proceso Civil, Proceso y Constitución: Las Garantías del Justo Proceso”, Palestra Editores (2013), 385 .

132 Political Constitution of Peru, Enacted 29 December 1993, English Translation by the Congress of the Republic (September 2009), Art. 2.12, available at: http://www.congreso .gob.pe/Docs/files/CONSTITUTION_27_11_2012_ENG.pdf.

133 Corte Suprema de Justicia, Recurso de Nulidad No. $5^{-02-2008, ~ p . ~} 20$ (Point 6C), available at: http://www.idehpucp.pucp.edu.pe/images/documentos/anticorrupcion/ jurisprudencia/recurso_nulidad_congresistas_05-02-2008.pdf; Villa Garcíaio, supra note 131 , at 385 .

134 Australian Law Reform Committee, "Discretionary and Mandatory Exclusions", Uniform Evidence Law (ALRC Report 102), para. 16.81, available at https://www.alrc. gov.au/publications/16.\%2oDiscretionary\%2oand\%2oMandatory\%2oExclusions/ exclusion-improperly-or-illegally-obtained-e\#.

135 "Impropriety" is essentially defined as interrogation under substantial impairment of the person to respond rationally, or under deception. Ibid., para. 16.77.

${ }_{13} 6$ Northern Territory of Australia, Evidence (National Uniform Legislation Act), as in force at 30 November 2018, Section 138(1), available at: https://legislation.nt.gov.au/Pages/ Act\%2oHistory?itemId =7e42c176-b2aa-49c2-bbc2-2fe88ddf7c4c. 
of action or offence, or the importance of the evidence for the proceedings. ${ }^{137}$ Various states and territories across Australia have already adopted Evidence Acts modelled on the National Uniform Legislation Act. ${ }^{138}$ The balancing test restates in large part a discretion developed in jurisprudence, most notably in Bunning v. Cross. ${ }^{139}$

The Australian balancing test combines factors also observed in other countries. The Code of Civil Procedure of Germany, for instance, does not explicitly regulate the admission of unlawfully acquired evidence. ${ }^{140}$ However, both the German Supreme Court and the German Constitutional Court have held that admission or exclusion must be decided on a case-by-case basis, considering certain factors in a balancing test. ${ }^{141}$ In particular, this balancing test should take into account the protective purpose of the law (Schutzzweck der Norm), whether violations of constitutional rights were at stake, ${ }^{142}$ and how serious the infringement of rights on both sides was (so that, arguably, illegally obtained videotapes may be inadmissible in case of simple theft, but admissible in case of battery and assault). ${ }^{143}$ Similarly, Switzerland's Civil Procedure Code stipulates in Article 152, paragraph 2, that "[i]llegally obtained evidence

137 The paragraph reads: "(a) the probative value of the evidence; and (b) the importance of the evidence in the proceeding; and (c) the nature of the relevant offence, cause of action or defence and the nature of the subject-matter of the proceeding; and (d) the gravity of the impropriety or contravention; and (e) whether the impropriety or contravention was deliberate or reckless; and (f) whether the impropriety or contravention was contrary to or inconsistent with a right of a person recognised by the International Covenant on Civil and Political Rights; and (g) whether any other proceeding (whether or not in a court) has been or is likely to be taken in relation to the impropriety or contravention; and (h) the difficulty (if any) of obtaining the evidence without impropriety or contravention of an Australian law."

138 I.e. the Commonwealth of Australia, New South Wales, Victoria, Tasmania, the Northern Territory and Australian Capital Territory. See David Caruso, "Public Policy and Private Illegality in the Pursuit of Evidence", 21 The International Journal of Evidence \& Proof (2017), 87, 101; Uniform Evidence Manual, Published in Melbourne by the Judicial College of Victoria, available at: http://www.judicialcollege.vic.edu.au/eManuals/UEM/28738. htm.

139 Caruso, supra note 138, at 102; Uniform Evidence Manual, Published in Melbourne by the Judicial College of Victoria, available at: http://www.judicialcollege.vic.edu.au/eManuals/ UEM/28738.htm.

140 Stephan Balthasar, "Beweisverwertungsverbote im Zivilprozess", Juristische Schulung (JuS) (2008), 35 .

141 Ibid., at 39 .

142 Ibid., at 38.

143 See Oberlandesgericht Köln, Case No. 24 U 12/05, Judgment of 5July 2005, para. 16, available at: https://www.justiz.nrw.de/nrwe/olgs/koeln/j2005/24_U_12_05urteil20050705.html. 
shall be considered only if there is an overriding interest in finding the truth."144 In its decision, the court must consider, on the one hand, whether the proceedings are governed by the principle of judicial investigation (Offizialmaxime) or the principle of party presentation (Verhandlungsmaxime). ${ }^{145}$ On the other hand, it must weigh the rank of the legally protected interests infringed, the intensity of the infringement and whether the affected party had a duty to cooperate. ${ }^{146}$ According to South African law, there is a judicial discretion to exclude illegally or improperly obtained evidence in civil matters. ${ }^{147}$ The threshold for admission is that it "would not lead to an unfair trial, or would not bring the administration of justice into disrepute."148 Nigeria adopted legislation that is strikingly similar to the Australian Evidence Act. ${ }^{149}$ Section 14 of the Nigerian Evidence Act 2011, which lists the factors to be considered in the balancing test, is in fact identical to the Australian list, except that consideration of the International Covenant on Civil and Political Rights (ICCPR) was left out. ${ }^{150}$ Another example of hinging the decision on admissibility of illegally obtained evidence on a weighing of interests is Kenya's Constitution, which in its Article 50(4) provides that it shall be "excluded if the admission of that evidence would render the trial unfair, or would otherwise be detrimental to the administration of justice."151

144 Swiss Civil Procedure Code (Civil Procedure Code, CPC) of 19 December 2008 (Status as of 1 January 2018), Art. 152(2), available at: https://www.admin.ch/opc/en/ classified-compilation/20061121/20180101000o/272.pdf; Natalia Kisliakova, "Using illegally obtained evidence in the Court of Arbitration for Sport", 16 February 2018, available at: http://www.cisarbitration.com/2018/o2/16/using-illegally-obtained-evidence-in-the -court-of-arbitration-for-sport/.

145 BGE 140 III 6, No. 4A_294/2013, 11 December 2013, Tribunal fédéral, La première Cour de droit civil, p. 11 (confirming that "dans une cause de nature patrimoniale soumise à la maxime des débats comme celle opposant les parties, l'intérêt à la découverte de la vérité matérielle, résultant prétendument du moyen de preuve illicite, ne saurait prévaloir face à l'intérêt public au respect strict de la règle de la confidentialité").

146 Christian Leu, "Art. 152 Recht auf Beweis", in A. Brunner, D. Gasser and I. Schwander (eds.), ZPO Schweizerische Zivilprozessordnung: Kommentar (2nd edition, 2016), 1153.

147 Wouter Le R De Vos, "Illegally or unconstitutionally obtained evidence: a South African perspective", 2 Journal of South African Law (2011), 279-28o; Lotter v. Arlow, 9220026 SA 6o ("This Court has a discretion to exclude evidence in civil matters which has been obtained in violation of the Constitution or ... by a criminal act or otherwise improperly.").

148 Lutter v. Arlow, supra note 147, para. 64F.

149 Stephen Oluwaseun Oke, "The Nigerian law on the admissibility of illegally obtained evidence: a step further in reform", 40(1) Commonwealth Law Bulletin (2014) 3, 11.

150 Nigeria, Evidence Act 2011, 3 June 2011, available at: https://www.refworld.org/ docid/54f86b844.html [accessed 28 November 2019].

$15^{1}$ The Constitution of Kenya, 2010, National Council for Law Reporting, available at: https:// www.wipo.int/edocs/lexdocs/laws/en/ke/keorgen.pdf; Jamil Ddamulira Mujuzi, "The 


\subsection{Conclusion - the Balancing of Interests as a Common Solution}

This brief survey has shown two things. First, there are great differences in the way unlawfully obtained evidence is regulated nationally: it is either not regulated at all, hence admissible; or regulated by making the inadmissibility absolute, or contingent on a constitutional violation or balancing test. Second, however, countries that decide the matter by means of a balancing test use similar factors. These factors, in part, also correspond to what international courts and tribunals have considered in their jurisprudence. Although the insufficient uniformity of national jurisdictions does not allow for an independent general principle of inadmissibility to be derived from national laws, one important inference is possible. If one decides to create a regime governing such evidence in international adjudication - potentially motivated by the clear rejection of the unlawful obtaining of evidence in Corfu Channel and based on guiding principles such as the proper administration of justice, or good faith - this regime could follow the approach taken by the countries surveyed here, and the courts and tribunals discussed above: a discretionary decision on admissibility after a balancing of certain factors. The factors that crystallized in the survey of national laws may be categorized into four distinct groups:

(1) factors related to the law breached: the rank of the law infringed (constitutional or fundamental rights), and its protective purpose;

(2) factors related to the breach: the intensity or gravity of the infringement or contravention, and whether the breach was deliberate or reckless;

(3) factors related to the evidence: the possibility to obtain the evidence in a legally proper way and the difficulty of such method; the probative value or the reliability of the evidence; the importance of the evidence for the proceedings;

(4) factors related to the proceedings: the nature of the case and its subjectmatter; whether admitting the evidence would jeopardize the conduct of a fair trial.

Even if general principles exist in national systems, they may not automatically translate into principles applicable in international law due to structural

Admissibility of Evidence Obtained in a Manner that Violates Human Rights under the 2010 Kenyan Constitution: How Courts Could Interpret Article 5o(4)", 2 International Human Rights Law Review (2013), 151, 152. 
differences between the systems. ${ }^{152}$ It is indeed true that the issues faced in international disputes are distinct, not only due to the sovereignty of the parties, but also since courts face more problems in obtaining evidence and are greatly reliant on the evidence provided to them. ${ }^{153}$ This article therefore argues for a solution that meets the special needs of the international legal system by providing the necessary flexibility, while setting clear standards that enhance transparency for states. Admittedly, the courts' broad powers already allow them to ascertain the weight and relevance of particular evidence, and the experienced international benches will not need 'protection' from potentially unreliable evidence. ${ }^{154}$ However, it is also obvious that the great potential for abuse in the field of unlawfully acquired evidence, coupled with widespread confusion as to how such evidence should be dealt with by judicial bodies, creates an undesirable status quo.

Courts and tribunals of general jurisdiction could proceed in two ways. They could either clarify their approach towards unlawfully obtained evidence by introducing a discretionary test in their 'codes' of evidentiary rules, or they could establish such a test by way of clearer statements in their jurisprudence constante on how such evidence is considered and evaluated. ${ }^{155}$ Although the first method is generally characterized as unrealistic, ${ }^{156}$ the latter method, namely a "court-led process of ongoing review and refinement through practice", 157 may be the appropriate way to achieve higher predictability, greater deterrence, and better guarantees of procedural rights.

As this survey of both international rules and jurisprudence as well as national systems has elucidated, there are common factors considered in balancing tests for illegally obtained evidence. A potential proposal could therefore use the categories established above (see supra, 4.2.5), complemented by criteria considered in international jurisprudence (see supra, 3.5). An international

152 Giorgio Gaja, "General Principles of Law", in R. Wolfrum (ed.), Max Planck Encyclopedia of Public International Law (2012), 372; Shabtai Rosenne, The Law and Practice of the International Court (1985), 557 (stating that "the restrictions upon admissibility of evidence sometimes encountered in national procedure have no place in international adjudication, where the relevance of facts and the value of evidence tending to establish facts are left to the entire appreciation of the court").

153 Riddell and Plant, supra note 6, at 3; Joyce, supra note 4, at 285.

154 Eduardo Valencia-Ospina, "Evidence before the International Court of Justice", 1 International Law Forum Du Droit International (1999), 205.

155 Riddell and Plant, supra note 6, at 417; Brendan Plant, "Expert Evidence and the Challenge of Procedural Reform in International Dispute Settlement", 9 Journal of International Dispute Settlement (2018), 468-469.

156 Plant, supra note 155 , at 468.

157 Ibid., p. 469. 
court or tribunal could therefore declare evidence as inadmissible if it was obtained in violation of rules of international law (or in a manner capable of seriously jeopardizing the integrity of the proceedings), if consideration of the following factors weighs in favor of discretionary exclusion:

(1) factors related to the law breached: the rights violated in the process of obtaining the evidence (their rank and protective purpose);

(2) factors related to the breach: whether the unlawful act of obtaining the evidence was deliberately directed at obtaining the evidence, or whether it was obtained incidental to an independent unlawful act;

(3) factors related to the evidence: whether the evidence was obtained without involvement of the party introducing it; whether the evidence was publicly available prior to the proceedings; the relevance or significance of the evidence for the proceedings; the possibility to obtain the evidence without a violation, or the difficulty of proving the fact through other evidentiary material; the probative value of the evidence (reliability, authenticity and accuracy);

(4) factors related to the proceedings: the nature and subject-matter of the proceedings, or cause of action; the gravity of the violation or antithetical nature of the act by which the evidence was obtained, compared to the seriousness of the alleged internationally wrongful act that the evidence is used to prove.

Special treatment of such evidence is warranted, on the one hand, by the principles of proper administration of justice, good faith and ex iniuria ius non oritur, and on the other hand, by a desirable policy of deterring state misconduct and fostering unity of the international legal system. A 'regulated discretion' would give freedom to the court to admit or exclude unlawfully obtained evidence, but would also require it to consider specific factors in a balancing test. A clear test on unlawfully acquired evidence would signal to states susceptible to abusing their freedom in collecting evidence that - as Judge Rosalyn Higgins has emphasized - "it is time to move away from undue deference to the litigants by virtue of their rank as sovereign states."158

$15^{8}$ Rosalyn Higgins, "Respecting Sovereign States and Running a Tight Courtroom", 50(1) International \& Comparative Law Quarterly (2001), 124. 